\title{
Responses of chemical composition, amino acid and fatty acid profiles of breast muscle to dietary crude fibre levels in China Micro-Ducks
}

\author{
S.P. Wang ${ }^{1,2,3 \#}$, D.M. Luo ${ }^{1,2}$, G.W. Liu ${ }^{1,2}$, M.J. Yin ${ }^{1,3}$, C.F. Zhou ${ }^{1,3}$, \\ X.L. Zhao ${ }^{1,3}$ \& Y.B. Guo ${ }^{1,2}$ \\ ${ }^{1}$ College of Animal Science, Southwest University, Chongqing, P.R. China \\ ${ }^{2}$ Xishui Fuxing Husbandry Co., Ltd., Xishui 556400, P.R. China \\ ${ }^{3}$ Baiyu Muwang Agricultural Science and Technology Co., Ltd. / Baiyu Yumu Kangyuan Husbandry Co., Ltd., \\ Bayu 627150, P.R. China
}

(Received 29 November 2018; Accepted 23 February 2019; First published online 23 May 2019)

\author{
Copyright resides with the authors in terms of the Creative Commons Attribution 4.0 South African License. \\ See: http://creativecommons.org/licenses/by/4.0/za \\ Condition of use: The user may copy, distribute, transmit and adapt the work, but must recognize the authors and
} the South African Journal of Animal Science.

\begin{abstract}
The effects of dietary crude fibre (CF) levels on the chemical composition, amino acid (AA) and fatty acid (FA) profiles of breast muscle in male China Micro-ducks (21 - $56 \mathrm{~d}$ ) were investigated in this study. The birds were randomly allocated to four treatments, of which dietary CF levels were 16.7, 42.6, 77.9 and 101.6 $\mathrm{g} / \mathrm{kg}$ of dry matter (DM), respectively. No influences on the proportions of crude ash, crude protein, lysine, methionine, threonine, phenylalanine, histidine, arginine, aspartic acid, glutamic acid, glycine, alanine, serine, cysteine, tyrosine, proline, C12:0, C18:0, C18:1n9, C20:0 and C22:1n9 in muscle were observed across the treatments. Consequently, the concentrations of semi-essential $A A$, non-essential AA, total AA, aromatic AA and delicious $A A$ in muscle, along with the $\Delta$-9-desaturase (18) index, were not affected by the treatments. Significant lower concentrations of valine, leucine, isoleucine, essential $A A$, branched-chain AA, C16:1n7 and monounsaturated FA in muscle, along with a lower ratio of branched-chain to aromatic AA, were noted in a dietary treatment with a CF level of $16.7 \mathrm{~g} / \mathrm{kg}$ DM compared to other dietary treatments. The rise of the dietary CF level significantly increased the proportions of DM, ether extract, gross energy, C18:2n6, C18:3n3, C20:4n6, unsaturated $F A$, total $F A$, polyunsaturated $F A, n-3$ polyunsaturated $F A, n-6$ polyunsaturated $F A$, essential FA, and the $\triangle$-9-desaturase (16) index. Furthermore, the rise of the dietary CF level increased the ratios of unsaturated to saturated $F A$, polyunsaturated to saturated $F A$, and $n-6$ to $n-3$ polyunsaturated $F A$ in muscle. However, it decreased the atherogenic index and the proportions of C14:0, C16:0, and saturated FA significantly. In conclusion, depending largely on dietary levels, CF profoundly and positively influenced the nutritional quality of breast muscle, especially the FA profile.
\end{abstract}

\footnotetext{
Keywords: China Micro-duck, dietary fibre, fatty acid, nutritional quality of meat, fatty acid

\# Corresponding author: wangshuiping1979@sina.com
}

\section{Introduction}

Protein from duck meat has played an indispensable role in satisfying the nutritional requirements of a growing world population of humans for high quality protein (Adeola, 2006). Duck meat is becoming increasingly popular worldwide because of its appetising flavour, nutritious value, taste and delicate texture (Liao et al., 2010). In recent years, there has been increased awareness of the manipulation of duck meat quality in order to obtain specific nutritional properties. China Micro-duck (CMD) is a complete set line which was developed from selective hybridisation between several specialised native and domestic sheldrakes/shelducks (Wang et al., 2013). In the actual production process, it was found that the CMD has a strong resistance to a wide range of fibrous feedstuffs (Wang et al., 2017).

It is known that in poultry nutrition dietary fibre may have beneficial physiological effects, as well as negative effects (Mateos et al., 2012). Mateos et al. (2012) concluded that the response to fibre supplementation depends on the source and level of dietary fibre and the characteristics of the diet as well as the physiological status and health of the bird. Dietary fibre has an impact on poultry owing to a multitude of aspects such as feed intake, digestive passage rate, gastrointestinal tract development, digestive enzyme 
secretion, nutrient utilisation, production performance, animal physiochemical status, body health, gut microbiota, bird behaviour and animal welfare, and contributes to the characteristic flavour of meat (Mead et al., 1983). Therefore, if the practical application of dietary fibre in poultry diets results in characteristic features in meat quality, a producer can supply specific poultry products to satisfy the requirements of consumers for meat with particular attributes pertaining to appearance, taste, texture and nutrients (He et al., 2015).

However, little information is available on the relationship between dietary fibre and meat quality in poultry. In addition, ducks have never been utilised as experimental animal species to reveal the interactions between dietary fibre and poultry. According to He et al. (2015), dietary fibre sources, which were mainly from corn straw silage, steam-exploded corn straw, steam-exploded wheat straw and steam-exploded rice straw, affected the protein proportion, cholesterol content and fatty acid (FA) profile of breast muscle in growing male Graylag geese. It was hypothesised that high-quality duck meat would result from the intake of diets with different crude fibre (CF) levels. The present study was designed to determine the differences in chemical composition, amino acid (AA) and FA profiles of breast muscle from male CMD in response to dietary CF levels during the growing period.

\section{Materials and Methods}

The experimental design and procedures were approved by the Animal Care and Use Committee of Southwest University following the requirements of the Regulations for the Administration of Affairs Concerning Experimental Animals of China (The State Science and Technology Commission, 1988). The bird husbandry and the experimental design have been described in detail by Wang et al. (2017).

Table 1 Ingredients and nutrient composition of the experimental diets ${ }^{1}$

\begin{tabular}{lcccc}
\hline \multirow{2}{*}{ Item } & \multicolumn{3}{c}{ Dietary crude fibre levels (g/kg of dry matter) } \\
\cline { 2 - 5 } & $\mathbf{1 6 . 7}$ & $\mathbf{4 2 . 6}$ & $\mathbf{7 7 . 9}$ & $\mathbf{1 0 1 . 6}$ \\
\hline Ingredients composition (g/kg) & & & \\
$\quad$ Purified corn starch & & & \\
Corn & 652.0 & 442.0 & 272.0 & 177.0 \\
Fish meal & - & 160.0 & 265.0 & 280.0 \\
Corn gluten meal & 290.0 & 210.0 & 115.0 & 70.0 \\
Alfalfa meal & - & 45.0 & 120.0 & 150.0 \\
Soybean oil & - & 65.0 & 130.0 & 205.0 \\
Calcium hydrogen phosphate & - & 20.0 & 40.0 & 60.0 \\
Calcium carbonate & 15.0 & 15.0 & 15.0 & 15.0 \\
Sodium chloride & 10.0 & 10.0 & 10.0 & 10.0 \\
Premix & 3.0 & 3.0 & 3.0 & 3.0 \\
Analyzed chemical composition (g/kg or otherwise & 30.0 & 30.0 & 30.0 & 30.0 \\
Dry matter & 873.3 & & & \\
Gross energy (MJ/kg) & 18.46 & 18.50 & 18.83 & 19.01 \\
Crude fibre & 16.7 & 42.6 & 77.9 & 101.6 \\
Crude protein & 216.1 & 220.1 & 218.3 & 219.9 \\
Ether extract & 39.5 & 41.3 & 49.9 & 55.0 \\
Crude ash & 81.4 & 80.4 & 76.9 & 72.1 \\
Calcium & 16.0 & 15.0 & 14.7 & 14.9 \\
Total phosphorus & 7.4 & 7.1 & 6.7 & 6.7 \\
& & & &
\end{tabular}

\footnotetext{
${ }^{1}$ All values were expressed on a dry matter basis except for the dry matter on an air-dried matter basis

${ }^{2}$ A sample of 1 kilogram of feed contains: vitamin A, $13000 \mathrm{IU}$; vitamin $\mathrm{D}_{3}, 5300 \mathrm{IU}$; vitamin $\mathrm{E}, 50 \mathrm{IU}$; vitamin $\mathrm{K}_{3}, 4 \mathrm{mg}$; vitamin $B_{1}, 3 \mathrm{mg}$; vitamin $B_{2}, 10 \mathrm{mg}$; vitamin $B_{6}, 7 \mathrm{mg}$; vitamin $B_{12}, 12 \mathrm{mg}$; folic acid, $2 \mathrm{mg}$; biotin, $170 \mathrm{mg}$; calcium pantothenate, $33 \mathrm{mg}$; nicotinic acid, $86 \mathrm{mg}$; Fe $\left(\mathrm{FeSO}_{4} \cdot 7 \mathrm{H}_{2} \mathrm{O}\right), 100 \mathrm{mg}$; $\mathrm{Cu}\left(\mathrm{CuSO}_{4} \cdot 5 \mathrm{H}_{2} \mathrm{O}\right), 10 \mathrm{mg} ; \mathrm{Zn}\left(\mathrm{ZnSO}_{4} \cdot 7 \mathrm{H}_{2} \mathrm{O}\right), 53$ $\mathrm{mg} ; \mathrm{Mn}\left(\mathrm{MnSO}_{4} \cdot \mathrm{H}_{2} \mathrm{O}\right), 80 \mathrm{mg}$; $\mathrm{Se}\left(\mathrm{Na}_{2} \mathrm{SeO}_{3} \cdot 5 \mathrm{H}_{2} \mathrm{O}\right), 0.2 \mathrm{mg}$; and I $(\mathrm{KI}), 0.44 \mathrm{mg}$
} 
The experimental diets (Table 1) were formulated to meet or exceed the NRC (1994) recommendations for growing ducks. The concentrations of dietary crude protein (CP) and apparent metabolisable energy were set up according to the proposal of Wang et al. (2013). All diets were semipurified and had similar ingredients and nutrients; in particular, four diets were isonitrogenous and isoenergetic. Each experimental diet was in pellet form with a particle size of $2.5 \mathrm{~mm}$.

The levels of CF in the experimental diets were 16.7, 42.6, 77.9 and $101.6 \mathrm{~g} / \mathrm{kg}$ of dry matter (DM). The variation in dietary CF level was achieved by altering the amount of alfalfa meal in the diet. Samples $( \pm 1$ $\mathrm{kg} / \mathrm{diet}$ ) from the experimental diets were randomly collected and then finely ground to pass a 1-mm sieve for further analysis. The results of the proximate, AA, and FA compositions in the experimental diets are shown in Tables 1, 2 and 3, respectively.

Table 2 Determined amino acid composition of the experimental diets ( $\mathrm{g} / \mathrm{kg}$ as dry matter basis)

\begin{tabular}{lcccc}
\hline \multirow{2}{*}{ Item } & \multicolumn{4}{c}{ Dietary crude fibre levels (g/kg of dry matter) } \\
\cline { 2 - 5 } & $\mathbf{1 6 . 7}$ & $\mathbf{4 2 . 6}$ & $\mathbf{7 7 . 9}$ & $\mathbf{1 0 1 . 6}$ \\
\hline Lysine & 16.6 & 16.1 & 17.1 & 16.9 \\
Methionine & 3.0 & 3.4 & 3.1 & 3.3 \\
Threonine & 8.3 & 7.8 & 7.6 & 7.4 \\
Valine & 10.7 & 10.4 & 9.5 & 9.8 \\
Leucine & 19.9 & 21.2 & 20.6 & 22.0 \\
Isoleucine & 7.3 & 6.9 & 6.8 & 6.7 \\
Phenylalanin & 9.5 & 10.3 & 9.3 & 9.6 \\
Histidine & 2.7 & 3.2 & 2.8 & 3.2 \\
Arginine & 11.5 & 11.2 & 10.3 & 10.9 \\
Aspartic acid & 11.8 & 12.4 & 12.5 & 12.2 \\
Glutamic acid & 29.5 & 30.1 & 30.6 & 29.8 \\
Glycine & 10.2 & 10.4 & 10.6 & 10.2 \\
Alanine & 11.0 & 11.8 & 11.5 & 11.3 \\
Serine & 8.3 & 8.2 & 8.8 & 8.2 \\
Cysteine & 5.4 & 5.0 & 4.7 & 4.7 \\
Tyrosine & 5.3 & 6.3 & 5.8 & 5.7 \\
Proline & 14.5 & 16.1 & 15.0 & 15.6 \\
Essential amino acid & 75.3 & 76.1 & 74.0 & 75.7 \\
Semi-essential amino acid & 14.2 & 14.4 & 13.1 & 14.1 \\
Non-essential amino acid & 96.0 & 100.3 & 99.5 & 97.6 \\
Total amino acid & 185.5 & 190.8 & 186.6 & 187.4 \\
& & & & \\
\hline
\end{tabular}

At $56 \mathrm{~d}$, after a 12-h fast with free access to water, two birds close to the average weight of each pen (six pens/group) were randomly selected from each replicate. Thus, 12 birds from each group were slaughtered to harvest the breast muscle (pectoralis major). The birds (48 in total) were stunned via electro anaesthetic, bled immediately through cutting carotid arteries, and partial slicing of the neck by a manual neck cutter; the feathers and the horny layers of claw and beak were removed following scalding. The stripped breast muscle of each bird was manually dissected with surgical blades from the eviscerated carcass, and excluded the skins, subcutaneous fats, bones and tendons. All the muscles were freeze-dried immediately, then ground by hand with a mortar and pestle to become meat powder for analysis.

The diet and meat samples were analysed for DM, crude ash (AS), CP, ether extract (EE), gross energy (GE), and $A A$ and FA profiles. In addition, CF, calcium and total phosphorus in the diets were assayed. All assays were conducted in triplicate. DM, CA, CF, CP, EE, calcium and total phosphorus were determined by the official methods (AOAC, 2005). GE was measured using an isoperibol bomb calorimeter XRY-1C (Henghe Instrument Company, China) with benzoic acid as a standard. 
Table 3 Determined fatty acid composition of the experimental diets ( $\mathrm{g} / \mathrm{kg}$ as dry matter basis)

\begin{tabular}{|c|c|c|c|c|c|}
\hline \multirow{2}{*}{ Item } & & \multicolumn{4}{|c|}{ Dietary crude fibre levels (g/kg of dry matter) } \\
\hline & & \multirow{2}{*}{$\begin{array}{c}16.7 \\
0.41\end{array}$} & \multirow{2}{*}{$\begin{array}{c}42.6 \\
0.46\end{array}$} & \multirow{2}{*}{$\begin{array}{l}77.9 \\
0.45\end{array}$} & \multirow{2}{*}{$\begin{array}{c}101.6 \\
0.45\end{array}$} \\
\hline Lauric acid & C12:0 & & & & \\
\hline Myristic acid & C14:0 & 0.86 & 0.90 & 0.67 & 0.76 \\
\hline Palmitic acid & C16:0 & 5.74 & 6.36 & 7.18 & 8.37 \\
\hline Palmitoleic acid & C16:1n7 & 0.66 & 0.67 & 0.55 & 0.58 \\
\hline Stearic acid & C18:0 & 1.78 & 1.95 & 2.10 & 2.90 \\
\hline Oleic acid & C18:1n9 & 9.65 & 10.86 & 13.22 & 14.06 \\
\hline Linoleic acid & C18:2n6 & 9.84 & 9.69 & 10.04 & 10.57 \\
\hline$\alpha$-Linolenic acid & C18:3n3 & 0.75 & 0.80 & 0.76 & 0.81 \\
\hline Arachidic acid & $\mathrm{C} 20: 0$ & 0.42 & 0.39 & 0.44 & 0.52 \\
\hline Arachidonic acid & C20:4n6 & 0.21 & 0.20 & 0.17 & 0.19 \\
\hline Erucic acid & C22:1n9 & 0.51 & 0.46 & 0.36 & 0.32 \\
\hline \multicolumn{2}{|c|}{ Saturated fatty acid } & 9.20 & 10.06 & 10.84 & 13.00 \\
\hline \multicolumn{2}{|c|}{ Unsaturated fatty acid } & 21.63 & 22.68 & 25.09 & 26.51 \\
\hline \multicolumn{2}{|c|}{ Unsaturated fatty acid/Saturated fatty acid } & 2.35 & 2.26 & 2.32 & 2.04 \\
\hline \multicolumn{2}{|l|}{ Total fatty acid } & 30.83 & 32.74 & 35.93 & 39.51 \\
\hline \multicolumn{2}{|c|}{ Monounsaturated fatty acid } & 0.66 & 0.67 & 0.55 & 0.58 \\
\hline \multicolumn{2}{|c|}{ Polyunsaturated fatty acid } & 20.96 & 22.01 & 24.54 & 25.93 \\
\hline \multicolumn{2}{|c|}{ Polyunsaturated fatty acid/Saturated fatty acid } & 2.28 & 2.19 & 2.26 & 2.00 \\
\hline \multicolumn{2}{|c|}{ n-3 Polyunsaturated fatty acid } & 0.75 & 0.80 & 0.76 & 0.81 \\
\hline \multicolumn{2}{|c|}{ n-6 Polyunsaturated fatty acid } & 10.05 & 9.89 & 10.21 & 10.75 \\
\hline \multicolumn{2}{|c|}{ n-6 Polyunsaturated fatty acid/n-3 Polyunsaturated fatty acid } & 13.33 & 12.33 & 13.49 & 13.33 \\
\hline \multicolumn{2}{|c|}{ Essential fatty acid } & 10.59 & 10.49 & 10.80 & 11.37 \\
\hline
\end{tabular}

The concentrations of 17 AA were quantified by high-pressure liquid chromatography (UPLC ${ }^{\circledR}$; Waters Corp., USA) following the procedure of Llames \& Fontaine (1994). The total AA was calculated by dividing the whole into three categories (Pellett \& Young, 1980; NRC, 1994). Essential AA (EAA) included lysine, methionine, threonine, valine, leucine, isoleucine and phenylalanine. Semi-essential AA (SEAA) contained histidine and arginine. Non-essential AA (NEAA) was composed of aspartic acid, glutamic acid, glycine, alanine, serine, cysteine, tyrosine and proline. Branched-chain AA (BCAA) was calculated as the sum of leucine, isoleucine and valine, while aromatic AA (AAA) was estimated as the total of tyrosine and phenylalanine and the ratio of The BCAA : AAA ratio was computed (FAONHO, 1973). Nourishing AA (DAA) comprised arginine, aspartic acid, glutamic acid, glycine and alanine (FAONHO, 1978).

Total fat was extracted using the direct FA methyl ester (FAME) synthesis method, described by O'Fallon et al. (2007). The FA composition of the FAME was determined on an Agilent Technologies 6890N gas chromatograph (Agilent Technologies, Inc., USA) equipped with an Agilent HP-88, $100 \mathrm{~m} \times 0.25 \mathrm{~mm}$ inner diameter $\times 0.20 \mu \mathrm{m}$ film column. FA analysis was performed by manual injection of $1 \mu \mathrm{L}$ of each sample. Eleven kinds of FA were identified by their retention time, in line with FA standards. The data on the FA composition were processed to compute the totalities of total FA, saturated FA (SFA), unsaturated FA (UFA), monounsaturated FA (MUFA), polyunsaturated FA (PUFA), n-3 PUFA, n-6 PUFA and essential FA (EFA). The ratios of UFA to SFA, PUFA to SFA and n-6 to n-3 PUFA were counted for their potential importance in poultry and human nutrition (Ulbricht \& Southgate, 1991; Wood et al., 2003). The atherogenic index (Al) was calculated according to the equation described by Ulbricht \& Southgate (1991):

$\mathrm{Al}=(\mathrm{C} 12: 0+(4 \times \mathrm{C} 14: 0)+\mathrm{C} 16: 0) /($ MUFA + PUFA $)$.

The index of the enzyme, $\Delta$-9-desaturase, responsible for the desaturation of two common SFAs (C16:0 and C18:0), was calculated according to the equations reported by Malau-Aduli et al. (1998):

$\Delta$-9-desaturase (16) index $=\mathrm{C} 16: 1 \mathrm{n} 7 /(\mathrm{C} 16: 0+\mathrm{C} 16: 1 \mathrm{n} 7) \times 100$

$\Delta$-9-desaturase (18) index $=\mathrm{C} 18: 1 \mathrm{c} 9 /(\mathrm{C} 18: 0+\mathrm{C} 18: 1 \mathrm{c} 9) \times 100$. 
A randomised design was utilised to evaluate the dietary effect. All data were subjected to a one-way analysis of variance by the GLM procedure of SAS (version 9.0, SAS Institute, Cary, NC) with dietary treatments as the classification factors. All the values were processed based on the average value of each pen as an experimental unit. Results were expressed as mean \pm standard deviation $(M \pm S D)$. Treatment means were compared using the Duncan's multiple range tests. Differences were considered significant when $P<0.05$.

\section{Results}

The basic chemical component data of breast muscle are presented in Table 4 . There was no difference $(P>0.05)$ in the proportions of CA and CP between the treatments. The birds fed the diet with a CF level of $16.7 \mathrm{~g} / \mathrm{kg} \mathrm{DM}$ had a lower $(P<0.05)$ DM proportion in muscle than those fed diets with CF levels of 77.9 and $101.6 \mathrm{~g} / \mathrm{kg} \mathrm{DM}$. No difference $(P>0.05)$ was observed in the proportions of EE and GE between the treatment with dietary CF level of 42.6 and $77.9 \mathrm{~g} / \mathrm{kg}$ of DM. However, the proportions of EE and GE in the breast muscle of birds on a diet with CF levels of 42.6 and $77.9 \mathrm{~g} / \mathrm{kg}$ DM were higher $(P<0.05)$ than those on a diet with a CF level of $16.7 \mathrm{~g} / \mathrm{kg} \mathrm{DM}$, but lower $(P<0.05)$ than those on a diet with a CF level of $101.6 \mathrm{~g} / \mathrm{kg} \mathrm{DM}$.

Table 4 Chemical composition of the male China Micro-duck breast muscle at 57 days of age ${ }^{1}$

\begin{tabular}{|c|c|c|c|c|c|c|}
\hline \multirow{2}{*}{ Item } & \multicolumn{4}{|c|}{ Dietary crude fibre levels (g/kg of dry matter) } & \multirow{2}{*}{$\mathrm{SEM}^{2}$} & \multirow{2}{*}{$P$-value } \\
\hline & 16.7 & 42.6 & 77.9 & 101.6 & & \\
\hline Dry matter (g/kg) & $216.9^{b} \pm 5.0$ & $221.8^{\mathrm{ab}} \pm 4.6$ & $222.6^{a} \pm 2.5$ & $225.7^{\mathrm{a}} \pm 6.8$ & 1.0 & 0.015 \\
\hline Crude ash $(\mathrm{g} / \mathrm{kg})$ & $56.0 \pm 0.8$ & $55.8 \pm 0.7$ & $55.8 \pm 0.4$ & $55.8 \pm 0.3$ & 0.1 & 0.863 \\
\hline Crude protein $(\mathrm{g} / \mathrm{kg})$ & $882.8 \pm 9.7$ & $886.3 \pm 7.3$ & $884.3 \pm 10.8$ & $885.0 \pm 8.9$ & 1.5 & 0.902 \\
\hline Ether extract $(\mathrm{g} / \mathrm{kg})$ & $70.0^{c} \pm 3.9$ & $79.6^{b} \pm 3.1$ & $80.0^{b} \pm 3.7$ & $84.4^{\mathrm{a}} \pm 1.8$ & 1.0 & 0.000 \\
\hline Gross energy $(\mathrm{MJ} / \mathrm{kg})$ & $22.26^{c} \pm 0.35$ & $23.30^{\mathrm{b}} \pm 0.33$ & $23.37^{\mathrm{b}} \pm 0.59$ & $23.83^{\mathrm{a}} \pm 0.31$ & 0.12 & 0.000 \\
\hline
\end{tabular}

Means with different superscripts $\left({ }^{\mathrm{a}, \mathrm{b}, \mathrm{c}}\right)$ within the same row differ at $P<0.05$

${ }^{1}$ All values were expressed on a dry matter basis except for the dry matter on a fresh matter basis

${ }^{2}$ SEM: standard error of mean

Information on AA composition and percentage of breast muscle is reflected in Table 5 . No effect of dietary CF levels on the contents of lysine, methionine, threonine, phenylalanine, histidine, arginine, aspartic acid, glutamic acid, glycine, alanine, serine, cysteine, tyrosine and proline was found $(P>0.05)$, and the concentrations of SEAA, NEAA, total AA, AAA and DAA were not affected $(P>0.05)$ by dietary treatments. Lower $(P<0.05)$ contents of valine, leucine, isoleucine, EAA and BCAA, and a lower $(P<0.05)$ BCAA to AAA ratio were observed in a dietary treatment with a CF level of $16.7 \mathrm{~g} / \mathrm{kg} D M$ compared to other dietary treatments.

Data on breast muscle FA composition and percentage are summarised in Table 6 . The change in dietary CF levels did not influence $(P>0.05)$ the proportions of C12:0, C18:0, C18:1n9, C20:0 and C22:1n9 or that of the $\Delta$-9-desaturase (18) index in muscle. The birds fed a diet with a CF level of $16.7 \mathrm{~g} / \mathrm{kg} \mathrm{DM}$ had lower $(P<0.05)$ C16:1n7 and MUFA proportions in muscle than the others. With increasing levels of dietary $\mathrm{CF}$, the proportions of C18:2n6, C18:3n3, C20:4n6, UFA, total FA, PUFA, n-3 PUFA, n-6 PUFA, EFA, or the $\triangle$-9-desaturase (16) index and the ratios of UFA to SFA, PUFA to SFA, and n-6 to n-3 PUFA increased ( $P$ $<0.05)$, but the Al and the proportions of C14:0, C16:0, and SFA decreased $(P<0.05)$.

\section{Discussion}

Very few studies have been conducted to appraise the effects of dietary fibre on the nutritional quality of poultry meat. There were almost no reports to investigate the relationship between dietary CF levels and the nutrient components of duck muscle. He et al. (2015) suggested that the types of dietary fibre sources resulted in significant differences in the proportion of protein, cholesterol content, and FA profile of breast muscle in growing male Graylag geese. In the present research, the vast majority of dietary CF was botanical and originated from alfalfa meal. Alfalfa, which is high-quality forage for ruminants, contains a considerable amount of insoluble fibre (McDonald et al., 2011). Yang (2002) asserted that alfalfa can be fed 
to waterfowl because the CF derived from alfalfa is largely digestible. According to production practice, it has been observed that CMD adapts well to various fibrous feedstuffs (Wang et al., 2013; Wang et al., 2017). The present results revealed that dietary fibre levels also altered the ratios of some constituents existing in the breast muscle of growing CMD.

Table 5 Amino acid profile of the male China Micro-duck breast muscle at 57 days of age ( $\mathrm{g} / \mathrm{kg}$ as dry matter basis)

\begin{tabular}{|c|c|c|c|c|c|c|}
\hline \multirow{2}{*}{ Item } & \multicolumn{4}{|c|}{ Dietary crude fibre levels (g/kg of dry matter) } & \multirow{2}{*}{ SEM $^{1}$} & \multirow{2}{*}{$\begin{array}{c}P- \\
\text { value }\end{array}$} \\
\hline & 16.7 & 42.6 & 77.9 & 101.6 & & \\
\hline Lysine & $71.1 \pm 0.1$ & $71.1 \pm 0.1$ & $71.1 \pm 0.1$ & $71.1 \pm 0.2$ & 0.0 & 0.879 \\
\hline Methionine & $21.3 \pm 0.2$ & $21.4 \pm 0.2$ & $21.4 \pm 0.3$ & $21.4 \pm 0.4$ & 0.0 & 0.956 \\
\hline Threonine & $34.4 \pm 0.6$ & $34.3 \pm 0.7$ & $34.4 \pm 0.6$ & $34.5 \pm 0.6$ & 0.1 & 0.986 \\
\hline Valine & $35.1^{b} \pm 0.2$ & $36.3^{\mathrm{a}} \pm 0.2$ & $36.4^{\mathrm{a}} \pm 0.3$ & $36.4^{\mathrm{a}} \pm 0.3$ & 0.1 & 0.000 \\
\hline Leucine & $66.7^{\mathrm{b}} \pm 1.7$ & $69.6^{\mathrm{a}} \pm 1.7$ & $69.4^{\mathrm{a}} \pm 1.7$ & $69.5^{\mathrm{a}} \pm 1.7$ & 0.3 & 0.006 \\
\hline Isoleucine & $34.1^{b} \pm 0.2$ & $35.2^{\mathrm{a}} \pm 0.3$ & $35.2^{\mathrm{a}} \pm 0.4$ & $35.2^{\mathrm{a}} \pm 0.3$ & 0.0 & 0.000 \\
\hline Phenylalanin & $30.7 \pm 0.0$ & $30.6 \pm 0.0$ & $30.7 \pm 0.1$ & $30.6 \pm 0.2$ & 0.0 & 0.724 \\
\hline Histidine & $21.9 \pm 0.2$ & $21.7 \pm 0.2$ & $21.6 \pm 0.2$ & $21.7 \pm 0.3$ & 0.0 & 0.311 \\
\hline Arginine & $53.7 \pm 0.0$ & $53.6 \pm 0.2$ & $53.7 \pm 0.1$ & $53.6 \pm 0.2$ & 0.0 & 0.616 \\
\hline Aspartic acid & $72.2 \pm 0.6$ & $71.8 \pm 0.7$ & $71.5 \pm 0.7$ & $71.7 \pm 1.1$ & 0.1 & 0.355 \\
\hline Glutamic acid & $122.1 \pm 4.9$ & $120.9 \pm 6.2$ & $121.0 \pm 4.3$ & $121.0 \pm 2.3$ & 0.7 & 0.952 \\
\hline Glycine & $46.7 \pm 2.3$ & $46.4 \pm 1.9$ & $46.5 \pm 2.2$ & $46.5 \pm 2.1$ & 0.3 & 0.991 \\
\hline Alanine & $49.1 \pm 2.2$ & $48.7 \pm 2.1$ & $48.8 \pm 2.1$ & $49.2 \pm 2.0$ & 0.3 & 0.951 \\
\hline Serine & $31.0 \pm 0.4$ & $30.9 \pm 0.6$ & $30.7 \pm 0.4$ & $30.7 \pm 0.4$ & 0.0 & 0.642 \\
\hline Cysteine & $9.9 \pm 0.6$ & $9.9 \pm 0.6$ & $9.4 \pm 0.8$ & $9.3 \pm 0.7$ & 0.1 & 0.288 \\
\hline Tyrosine & $23.8 \pm 2.1$ & $22.6 \pm 2.0$ & $22.6 \pm 2.1$ & $22.4 \pm 2.2$ & 0.3 & 0.590 \\
\hline Proline & $37.0 \pm 2.1$ & $36.4 \pm 2.2$ & $36.4 \pm 2.1$ & $36.5 \pm 1.9$ & 0.3 & 0.943 \\
\hline Essential amino acid & $293.7^{b} \pm 1.7$ & $298.8^{\mathrm{a}} \pm 1.7$ & $298.8^{\mathrm{a}} \pm 1.5$ & $299.0^{\mathrm{a}} \pm 1.5$ & 0.4 & 0.000 \\
\hline Semi-essential amino acid & $75.6 \pm 0.2$ & $75.3 \pm 0.3$ & $75.4 \pm 0.2$ & $75.4 \pm 0.4$ & 0.0 & 0.405 \\
\hline Non-essential amino acid & $392.1 \pm 14.6$ & $387.9 \pm 16.0$ & $387.2 \pm 13.9$ & $387.7 \pm 10.9$ & 2.3 & 0.892 \\
\hline Total amino acid & $761.5 \pm 16.0$ & $762.1 \pm 17.5$ & $761.5 \pm 15.2$ & $762.2 \pm 12.0$ & 2.5 & 0.937 \\
\hline Branched-chain amino acid & $136.0^{\mathrm{b}} \pm 1.3$ & $141.2^{\mathrm{a}} \pm 1.3$ & $141.1 \pm 1.2^{\mathrm{a}}$ & $141.2^{\mathrm{a}} \pm 1.3$ & 0.4 & 0.000 \\
\hline Aromatic amino acid & $54.5 \pm 2.1$ & $53.3 \pm 2.0$ & $53.3 \pm 2.1$ & $53.1 \pm 2.2$ & 0.3 & 0.563 \\
\hline Branched-chain/Aromatic amino acid & $2.49^{\mathrm{b}} \pm 0.07$ & $2.65^{\mathrm{a}} \pm 0.08$ & $2.64^{\mathrm{a}} \pm 0.08$ & $2.65^{\mathrm{a}} \pm 0.09$ & 0.01 & 0.001 \\
\hline Delicious amino acid & $344.0 \pm 9.4$ & $341.6 \pm 10.7$ & $341.7 \pm 8.9$ & $342.2 \pm 6.0$ & 1.5 & 0.946 \\
\hline
\end{tabular}

Means with different superscripts $\left({ }^{\mathrm{a}, \mathrm{b}}\right)$ within the same row differ at $P<0.05$

${ }^{1}$ SEM: standard error of mean

Dietary fibre improved poultry carcass quality by reducing the amount of fat deposits in the carcass (Yang, 2002; McDonald et al., 2011). Siregar et al. (1982) found that feeding White Pekin ducklings increased amounts of dietary fibre led to a reduction in carcass fat. However, the correlation between dietary fibre content and muscle fat is not clear. The current study found that a rise of CF levels in the diet enhanced the proportion of muscular fat. The amount of fat in the muscle positively influences meat tenderness and juiciness (Wood et al., 2003). Hence, higher levels of CF in the diet of growing CMD were beneficial to the quality of breast muscle. Meanwhile, with the increment in dietary CF levels, both the proportion of DM and the concentration of GE in muscle were heightened to some extent, implying that the unequal levels of dietary CF brought about some variations in the breast muscle components of duck.

Producing high quality protein is the main purpose of breeding duck for human consumption. Although no difference was found in the breast muscle CP proportion between several treatments, dietary 
CF levels somehow impacted the AA profile. The data showed that dietary fibre elevated the muscle EAA content due to the enhanced BCAA. The ratio of BCAA to AAA in muscle was also improved for the same reason, which illustrated that dietary fibre increased the quality of breast muscle because meat with a higher BCAA : AAA ratio is more beneficial to the protection of liver function (FAO/WHO, 1973). However, the beneficial results of the muscle AA profile stimulated by dietary fibre were limited. Only the contents of valine, leucine and isoleucine in the breast muscle were varied, but neither CP percentage nor total AA proportion were changed. The variations of three kinds of BCAA were not closely related to dietary CF levels because no difference was noticed between dietary treatments with CF level of 42.6, 77.6, and $101.6 \mathrm{~g} / \mathrm{kg} \mathrm{DM}$.

Table 6 Fatty acid profile of the male China Micro-duck breast muscle at 57 days of age $(\mathrm{g} / \mathrm{kg}$ as dry matter basis)

\begin{tabular}{|c|c|c|c|c|c|c|c|}
\hline \multirow{2}{*}{ Item } & & \multicolumn{4}{|c|}{ Dietary crude fibre levels (g/kg of dry matter) } & \multirow{2}{*}{ SEM $^{1}$} & \multirow{2}{*}{$\begin{array}{c}P \text { - } \\
\text { value }\end{array}$} \\
\hline & & 16.7 & 42.6 & 77.9 & 101.6 & & \\
\hline Lauric acid & C12:0 & $0.95 \pm 0.04$ & $0.92 \pm 0.06$ & $0.91 \pm 0.03$ & $0.90 \pm 0.06$ & 0.00 & 0.361 \\
\hline Myristic acid & C14:0 & $1.25^{a} \pm 0.02$ & $1.09^{b} \pm 0.04$ & $0.98^{c} \pm 0.07$ & $0.88^{d} \pm 0.03$ & 0.02 & 0.000 \\
\hline Palmitic acid & C16:0 & $15.26^{\mathrm{a}} \pm 1.28$ & $12.91^{\mathrm{b}} \pm 0.46$ & $12.91^{\mathrm{b}} \pm 0.81$ & $10.16^{c} \pm 1.35$ & 0.36 & 0.000 \\
\hline Palmitoleic acid & C16:1n7 & $1.53^{\mathrm{b}} \pm 0.10$ & $1.65^{a} \pm 0.10$ & $1.66^{a} \pm 0.09$ & $1.66^{a} \pm 0.09$ & 0.01 & 0.030 \\
\hline Stearic acid & C18:0 & $10.43 \pm 0.80$ & $10.29 \pm 0.64$ & $10.24 \pm 0.96$ & $10.24 \pm 1.07$ & 0.14 & 0.969 \\
\hline Oleic acid & C18:1n9 & $15.95 \pm 0.83$ & $16.45 \pm 1.84$ & $16.51 \pm 1.52$ & $16.68 \pm 0.84$ & 0.22 & 0.728 \\
\hline Linoleic acid & C18:2n6 & $4.30^{c} \pm 0.76$ & $7.81^{b} \pm 0.73$ & $10.14^{\mathrm{a}} \pm 0.59$ & $10.15^{\mathrm{a}} \pm 1.03$ & 0.45 & 0.000 \\
\hline$\alpha$-Linolenic acid & C18:3n3 & $0.49^{d} \pm 0.03$ & $0.67^{c} \pm 0.03$ & $0.82^{b} \pm 0.03$ & $0.90^{\mathrm{a}} \pm 0.07$ & 0.02 & 0.000 \\
\hline Arachidic acid & C20:0 & $0.64 \pm 0.04$ & $0.64 \pm 0.02$ & $0.64 \pm 0.02$ & $0.63 \pm 0.02$ & 0.00 & 0.826 \\
\hline Arachidonic acid & C20:4n6 & $3.85^{c} \pm 0.18$ & $5.09^{b} \pm 0.44$ & $6.91^{a} \pm 0.42$ & $7.13^{\mathrm{a}} \pm 0.63$ & 0.25 & 0.000 \\
\hline Erucic acid & C22:1n9 & $0.62 \pm 0.05$ & $0.63 \pm 0.02$ & $0.62 \pm 0.05$ & $0.64 \pm 0.03$ & 0.00 & 0.807 \\
\hline \multicolumn{2}{|c|}{ Saturated fatty acid } & $28.5^{a} \pm 1.96$ & $25.7^{\mathrm{b}} \pm 0.91$ & $25.7^{\mathrm{b}} \pm 0.91$ & $22.8^{c} \pm 2.12$ & 0.45 & 0.000 \\
\hline \multicolumn{2}{|c|}{ Unsaturated fatty acid } & $26.8^{\mathrm{c}} \pm 1.59$ & $32.3^{\mathrm{b}} \pm 1.87$ & $36.7^{\mathrm{a}} \pm 1.17$ & $37.2^{\mathrm{a}} \pm 1.80$ & 0.80 & 0.000 \\
\hline \multicolumn{2}{|c|}{ Unsaturated/Saturated fatty acid } & $0.93^{d} \pm 0.04$ & $1.24^{c} \pm 0.06$ & $1.42^{\mathrm{b}} \pm 0.06$ & $1.63^{\mathrm{a}} \pm 0.11$ & 0.04 & 0.000 \\
\hline \multicolumn{2}{|l|}{ Total fatty acid } & $55.3^{c} \pm 3.29$ & $58.2^{\mathrm{bc}} \pm 2.40$ & $62.4^{\mathrm{a}} \pm 1.62$ & $60.0^{\mathrm{ab}} \pm 3.59$ & 0.66 & 0.000 \\
\hline \multicolumn{2}{|c|}{ Monounsaturated fatty acid } & $1.53^{\mathrm{b}} \pm 0.10$ & $1.65^{\mathrm{a}} \pm 0.10$ & $1.66^{a} \pm 0.09$ & $1.66^{\mathrm{a}} \pm 0.09$ & 0.01 & 0.030 \\
\hline \multicolumn{2}{|c|}{ Polyunsaturated fatty acid } & $25.2^{\mathrm{c}} \pm 1.52$ & $30.7^{\mathrm{b}} \pm 1.84$ & $35.0^{\mathrm{a}} \pm 1.20$ & $35.5^{\mathrm{a}} \pm 1.85$ & 0.79 & 0.000 \\
\hline \multicolumn{2}{|c|}{ Polyunsaturated/Saturated fatty acid } & $0.88^{d} \pm 0.04$ & $1.18^{\mathrm{c}} \pm 0.06$ & $1.36^{\mathrm{b}} \pm 0.06$ & $1.56^{a} \pm 0.11$ & 0.04 & 0.000 \\
\hline \multicolumn{2}{|c|}{ n-3 Polyunsaturated fatty acid } & $0.49^{d} \pm 0.03$ & $0.67^{c} \pm 0.03$ & $0.82^{\mathrm{b}} \pm 0.03$ & $0.90^{a} \pm 0.07$ & 0.02 & 0.000 \\
\hline \multicolumn{2}{|c|}{ n-6 Polyunsaturated fatty acid } & $8.15^{c} \pm 0.78$ & $12.90^{\mathrm{b}} \pm 0.88$ & $17.05^{\mathrm{a}} \pm 0.51$ & $17.29^{\mathrm{a}} \pm 1.17$ & 0.68 & 0.000 \\
\hline \multicolumn{2}{|c|}{ n-6/n-3 Polyunsaturated fatty acid } & $16.61^{\mathrm{c}} \pm 1.45$ & $19.04^{b} \pm 1.01$ & $20.65^{a} \pm 1.10$ & $19.24^{\mathrm{ab}} \pm 1.83$ & 0.35 & 0.000 \\
\hline \multicolumn{2}{|l|}{ Essential fatty acid } & $4.79^{c} \pm 0.78$ & $8.48^{\mathrm{b}} \pm 0.75$ & $10.96^{a} \pm 0.60$ & $11.06^{a} \pm 1.05$ & 0.47 & 0.000 \\
\hline \multicolumn{2}{|l|}{ Atherogenic index } & $0.79^{\mathrm{a}} \pm 0.04$ & $0.56^{\mathrm{b}} \pm 0.03$ & $0.48^{c} \pm 0.02$ & $0.39^{d} \pm 0.02$ & 0.02 & 0.000 \\
\hline \multicolumn{2}{|c|}{$\Delta$-9-desaturase (16) index } & $9.15^{c} \pm 0.74$ & $11.37^{\mathrm{b}} \pm 0.51$ & $11.43^{\mathrm{b}} \pm 0.55$ & $14.21^{\mathrm{a}} \pm 1.83$ & 0.36 & 0.000 \\
\hline \multicolumn{2}{|c|}{$\Delta$-9-desaturase (18) index } & $60.5 \pm 1.41$ & $61.4 \pm 2.42$ & $61.7 \pm 3.15$ & $62.0 \pm 2.88$ & 0.44 & 0.667 \\
\hline
\end{tabular}

Means with different superscripts $\left({ }^{\mathrm{a}, \mathrm{b}, \mathrm{c}, \mathrm{d}}\right)$ within the same row differ at $P<0.05$

${ }^{1}$ SEM: standard error of mean

The FA composition of meat always receives a great deal of attention in research because of its implications for human health (Raes et al., 2004). Besides a lower total fat intake, human nutritionists are recommending a higher consumption of PUFA and especially of $n-3$ PUFA at the expense of $n-6$ PUFA in order to reduce the risk of developing cardiovascular diseases (Hu et al., 2001; Wood et al., 2008). Consequently, maximising the muscle PUFA proportion, particularly that of $n-3$ PUFA, would enhance the nutritional value of meat $(\mathrm{WHO}, 2003)$. The FA profile of poultry meat is generally manipulated by using a selected feeding with particular nutritional characteristics. The on-going research provides an alternative 
strategy aimed at heightening the ratio of PUFA to SFA as well as ameliorating the FA profile in the breast muscle of ducks. The fact that the birds fed a diet with a higher CF level in the present study had a more optimal FA framework in muscle than those fed a diet with a lower CF level verified the above-mentioned deduction. The variations in the FA profile of breast muscle between dietary treatments could be attributed to different CF levels in the diet of ducks since the analysed compositions of proximate nutrients AA and FA for four experimental diets were very close to each other, except for the dietary CF levels. In addition, the responses of the descending $\mathrm{Al}$ as well as the ascending $\Delta-9$ desaturase activity index for C16 FA in muscle to the elevating levels of dietary CF illustrated that dietary fibre could encourage the antioxidant capacity and depress lipid oxidation so as to directly affect the sensory characteristics of meat and indirectly provide multiple health benefits to consumers (Wood et al., 2003).

\section{Conclusions}

The present study revealed the major differences resulting from dietary CF levels with regard to the nutritional quality of CMD breast muscle. Feeding the ducks a diet with a CF level of $101.6 \mathrm{~g} / \mathrm{kg}$ DM resulted in the highest concentrations of DM, EE and GE in muscle, as well optimal FA composition, indicating the superior potential of a high dietary fibre level to improve the lipid profile of meat to provide health benefits to consumers. The diet with a CF level of $16.7 \mathrm{~g} / \mathrm{kg}$ DM might be consumers' last choice because it brings about the lowest contents of DM, EE and GE as well as the worst profiles of AA and FA in muscle. Little variation existed in the composition of chemical components, AA, and most FA profiles in muscle between the treatment with dietary CF levels of 42.6 and $77.9 \mathrm{~g} / \mathrm{kg} \mathrm{DM}$, except for significant differences in the proportions of C14:0, C18:2n6, C18:3n3 and C20:4n6. Depending on dietary levels, CF has a positive effect on the nutritional quality of CMD breast muscle, especially the FA profile. However, in order to thoroughly evaluate the impact of dietary CF levels on meat quality of CMD, further trials are required to explore the relationship between consumer consumption, and the safety and technological aspects pertaining to the production of meat.

\section{Acknowledgments}

This work was financially supported partly by China Agriculture Research System (CARS-43-15), Sichuan Science and Technology Program (2019YFN0080) and Sichuan Provincial Government Procurement Project (5133312018000053).

\section{Authors' Contributions}

SPW, DML and GWL contributed equally to this work as the first co-authors.

\section{Conflict of Interest Declaration}

There is no conflict of interest.

\section{References}

Adeola, O., 2006. Review of research in duck nutrient utilization. International J. Poult. Sci. 5, 201-218.

AOAC, 2005. Official Methods of Analysis of AOAC International (18th ed.). Association of Official Analytical Chemists, Arlington, USA.

FAO/WHO, 1973. Energy and Protein Requirements: Report of a joint FAONHO ad hoc expert committee. WHO Technical Report Series No. 522, Geneva, Switzerland.

FAO/WHO., 1978. Energy and Protein Requirements: Report of a joint FAOMHO/UNU expert consultation technical report. Series No. 724, FAOMHO, Geneva, Switzerland.

He, L.W., Meng, Q.X., Li, D.Y., Zhang, Y.W. \& Ren, L.P., 2015. Meat quality, oxidative stability and blood parameters from Graylag geese offered alternative fiber sources in growing period. Poult. Sci. 94, 750-757.

Hu, F.B., Manson, J.E. \& Willett, W.C., 2001. Types of dietary fat and risk of coronary heart disease: A critical review. J. Am. Coll. Nutr. 20, 5-19.

Liao, G.Z., Wang, G.Y., Xu, X.L. \& Zhou, G.H., 2010. Effect of cooking methods on the formation of heterocyclic aromatic amines in chicken and duck breast. Meat Sci. 85, 149-154.

Llames, C.R. \& Fontaine, J., 1994. Determination of amino acids in foods: collaborative study. J. AOAC. 77, 1362-1402.

Malau-Aduli, A., Siebert, B.D., Bottema, C. \& Pitchford, W.S., 1998. Breed comparison of the fatty acid composition of muscle phospholipids in Jersey and Limousin cattle. J. Anim. Sci. 76, 766-773.

Mateos, G.G., Jiménez-Moreno, E., Serrano, M.P. \& Lázaro, R., 2012. Poultry response to high levels of dietary fiber sources varying in physical and chemical characteristics. J. Appl. Poult. Res. 21, 156-174.

McDonald, P., Edwards, R.A., Greenhalgh, J.F.D., Morgan, C.A., Sinclair, L.A. \& Wilkinson, R.G., 2011. Animal Nutrition (7th ed.). Benjamin Cummings, Pearson Education Limited, San Francisco, USA.

Mead, G.C., Griffiths, N.M., Impey, C.S. \& Cople-Stone, J.C., 1983. Influence of diet on the intestinal microflora and meat flavour of intensively-reared broiler chickens. Br. J. Nutr. 24, 261-272.

NRC., 1994. Nutrient Requirements of Poultry (7th ed.). The National Academies Press, Washington, USA.

O'Fallon, J.V., Busboom, J.R., Nelson, M.L. \& Gaskins, C.T., 2007. A direct method for fatty acid methyl ester synthesis: Application to wet meat tissues, oils, and feedstuffs. J. Anim. Sci. 85, 1511-1521. 
Pellett, P.L. \& Young V.R., 1980. Nutritional Evaluation of Protein Foods. The United National University Publishing Company, Tokyo, Japan.

Raes, K., De Smet, S. \& Demeyer, D., 2004. Effect of dietary fatty acids on incorporation of long chain polyunsaturated fatty acids and conjugated linoleic acid in lamb, beef and pork meat: A review. Anim. Feed Sci. Technol. 113, 199-221.

Siregar, A.P., Cumming, R.B. \& Farrell, D.I., 1982. The nutrition of meat-type ducks. 3. The effects of fibre on biological performance and carcass characteristics. Aust. J. Agric. Res. 33, 877-886.

The State Science and Technology Commission., 1988. Regulations for the Administration of Affairs Concerning Experimental Animals. The State Science and Technology Commission, Beijing, China.

Ulbricht, T.L.V. \& Southgate, D.A.T., 1991. Coronary heart disease: Seven dietary factors. Lancet 338, 985-992.

Wang, S.P., Peng, X.W. \& Xie, H.D., 2013. Requirements of crude protein and metabolizable energy of male China Micro-duck aged from 4 to 8 weeks. Chinese J. Anim. Nutr. 25, 1728-1739.

Wang, S.P., Wang, W.J., Yang, D.S., Zhao, X.L., Luo, D.M. \& Guo, Y.B., 2017. Growth, carcass, and physiological traits of growing male China Micro-ducks fed various levels of dietary crude fibre. Czech J. Anim. Sci. 62, 347-356.

WHO, 2003. Diet, nutrition and the prevention of chronic diseases: Report of a joint WHO/FAO expert consultation. World Health Organization, Geneva, Switzerland.

Wood, J.D., Richardson, R.I., Nute, G.R., Fisher, A.V., Campo, M.M., Kasapidou, E., Sheard, P.R. \& Enser, M., 2003. Effects of fatty acids on meat quality: A review. Meat Sci. 66, 21-32.

Wood, J.D., Enser, M., Fisher, A.V., Nute, G.R., Sheard, P.R., Richardson, R.I., Hughes, S.I. \& Whittington, F.M., 2008. Fat deposition, fatty acid composition and meat quality: A review. Meat Sci. 78, 343-358.

Yang, N., 2002. Poultry Science. China Agriculture Press, Beijing, China. 